graphical work is reported. The trigonometrical branch has necessarily been curtailed in its activities, the scientific work of that branch (astronomical, magnetic, and tidal) making un its chief record, with but little reference to the extension of geodetic triangulation. In the department of map publication there has been great activity, the total number of maps published $(626,329)$ during the year being in excess of that of the year previous.

T. H. H.

\section{MODERN DEVELOPMENTS OF THE GAS INDUSTRY.}

O WING to sudden illness, Mr. W. B. Worthington asked at the end of October to be released from the duties of the presidency of the Institution of Civil Engineers. Mr. Harry Jones, who has been elected to succeed him, delivered the presidential address before the institution on November $6 . \mathrm{Mr}$. Jones is the chairman of the High Explosives Committee, of which Lord Moulton is president, and is the first member of the gas engineering profession who has occupied the chair at the Institution of Civil Engineers. In his address he dealt with modern developments in gas practice, how far the practice has been making itself useful during the war, the fresh prospects it has in the coming time of peace, and, finally, the special qualification of the gas engineer and the work he has to do. Subjoined are extracts from the address.

There has come about in the work of the gas engineer an entire revolution. We used to be called "gas light companies," and the ancient Act of Parliament used to speak of "furnishing a luminous vapour." The revolution that I speak of is in the fact that the use of gas for direct lighting has become almost extinct, and there has been an enormous development of gas as pure fuel, both for domestic and trade purposes, as well as for motor-cars. So extensive has the growth been that it is estimated that, allowing for the use of incandescent mantle burners, not 5 per cent. of the whole output is now used for direct illumination.

The fuel and engine use varies as the towns are more or less industrial, but evidence is not wanting that that also is growing very rapidly. For instance, in the East of London the Royal Mint melts the whole of the coinage by gas furnaces, and Messrs. Rothschild's large refinery uses the same means of smelting. It is remarkable that the gas company which furnishes that supply, having made fuses for war purposes, was found to have by its furnaces melted the metal with such good effect as to produce an alloy so superior that the company has been specially asked to smelt metals on a large scale for the Munitions Department, and is now carrying out a considerable amount of smelting for that department, and you may be interested to learn that this is entirely done by women operators.

Sir Robert Hadfield has stated that in his Sheffield works he uses as much as 500,000,000 cub. ft. of gas per annum for smelting and metallurgical purposes, which represents the output of 45,000 tons of coal. Mr. Hanbury. Thomas, the manager of the Sheffield Gas Company, has stated that his company has no fewer than 642 furnaces, consuming $372,000,000$ cub. ft. of gas, at work in his district, while 15,116 h.p. gas engines consume $780,000,000 \mathrm{cub}$. ft. From Birmingham. Manchester, Glasgow, and, indeed, from all the manufacturing towns, we hear similar statements. For such purposes the cleanliness, flexibility, intensity of heat, and control of gas fuel must be very great considerations indeed. The effect of all these uses of gas has been to level the load factor and to remove the NO. 2509 , VOL. IOO] maximum demand peak from night-time in midwinter, which was formerly the time when people wanted special light, and often some heat; but to-day the midday cooking hour on a summer Sunday forms the peak in the industrial suburbs of London. There is no hour which demands so much gas as that particular hour on a July Sunday.

An important result of these extended uses of gas appliances has been their ready applicability to the rapid furnishing of munitions on emergency. Acknowledgment is due to makers of furnaces and stove plants for the aptitude and energy shown by them in forcing their output to meet the stress of war, in face of scarcity of materials and labour. Moreover, they have devised a great variety of useful and ingenious plant for facilitating processes of all kinds and for speeding up output, and these have been eagerly accepted by those engaged on munition works.

But, quite apart from general service of this kind, a special direct supply of high explosive material was effectively furnished at short notice in adequate quantities to the War Department, and, although I must not enlarge upon this, I have obtained Lord Moulton's permission to quote to you the full and generous recognition he has given publicly to these services of the gas industry. Among other complimentary and generous expressions he has stated:- "Without the direct aid of the gas industry, and, further than that, the assistance and the knowledge which have been acquired by those who devote their lives to it, it would have been perfectly impossible for this country to have waged the campaign of the last three years, or even for any but a trifling time resist the overwhelming floods of enemies that were poured upon it. When I first was asked to take charge of the manufacture and production of explosives, it took me but a few days to realise my absolute dependence on your great industry. My appeal to the leaders to assist me was made immediately. . . The response has been so splendid that we have become, I might almost say, affluent where I expected nothing but pauperism, and gradually we have seen ourselves creeping up to an equality with the supplies that our enemies have been piling up year after year in anticipation of a war that they intended to bring upon us, until now I think that our anxiety in this department, which at first was probably the keenest anxiety of all, has passed away through your assistance."

The explanation of this graceful acknowledgment is that at the time the appeal was made there was in the hands of the gas engineer neither a process nor plant for the recovery of one special requirement. For the best process the plant foundations and housing wanted months for execution. But Dr. Carpenter found that by using our own tar as a solvent at a suitable temperature and diverting part of our existing plant from its normal use, the greater part of the recovery could be effected at once, and that, too, by gasworks below the scale justifying the special plant being erected. Lord Moulton sanctioned this departure, and within a fortnight some of us got going on the Carpenter process, and began to "deliver the goods," which were at that time very vital. So much has been needed since that we have mostly installed the more complete plant on large-scale works, but no profit at all is got out of this; moreover, the service of the chiefs of the staff for organising the co-operation of all the gas undertakings in this work has been furnished by the gas companies without anv charge whatever to the Government, and many other accommodations have been gratuitously afforded.

The extended number and varietv of processes arising in the prosecution of war service generally in the furnishing of munitions inevitably lead us to the consideration of how far these processes will help us in 
times of peace in the future. Inevitably connected with the present distribution of gas as fuel, the chief residual, coke, though not valued as it deserves to be, is a useful smokeless fuel, and can oe converted into water-gas, and so made use of as a fuel. Ammonia, when fixed by the acid from our sulphur, is of great value as a fertiliser, and is wanted everywhere for the land. Tar yields chiefly pitch, which is also a fuel, but is needed for the repair of our roads. It is also the parent of many useful by-products. In the past it has been almost a drug in the market, chiefly, it is feared, through our own supineness in allowing the recovery processes largely to leave this country, although the country itself is a large buyer of most of the developed products. The sub-products can, for simplicity, be shortly grouped as follows:-There are ten products which, by their energetic combustion, are capable of explosion for war or motor fuel; there are nineteen various colour dyes of great brilliancy; there are nine drugs and antiseptics, among which are saccharine and aspirin; there are eight perfumes and flavourings; there are ten salts of ammonia and cyanogen, and one sulphur for acid-making and fixing ammonia and cyanogen; altogether fifty-seven, and these may be brought out by further permutations into an almost endless number of interesting and probably, in the future, most valuable products. For war purposes the first ten products and the last eleven are especially useful; but I must not tell you how or why, at any rate at present.

Most of these products, such as the drugs and dyes, have sprung into unexpected importance lately, owing to the limitation of imports due to the war. Their manufacture previously had been very largely appropriated by the Germans, who bought the raw products extensively in this country. Now, more wisely, the larger gas undertakings and newly formed British companies are increasing their production at home.

When the full value of these products is realised under peace conditions steps must be taken to prevent -as has long been done in Germany-the inevitable loss of these values where raw coal is burned to destruction, as in ordinary grates and furnaces under steam boilers. To this end there are important inquiries going on into the question of the conservation of coal as a national asset.

With regard to the general question of the destruction of fuel and of meeting other general needs, considering the now universal demand for gas and coke fuel, pitch for roads, benzol for motor transport, and ammonia for the land, to say nothing of the lesser products, it is surely wise to distribute their production where the population exists, and it is clear that the existing supply of gas, as at present arranged, lends itself to that distribution, as the population lies around the works. This will be true also, in a less degree, of even scattered rural populations, as they eagerly avail themselves of gas as a fuel, the distribution of coal being difficult and expensive in such small quantities. Through the extended use of gas already a very large amount of coal has been displaced for domestic and trade use, to the great improvement of the atmosphere and to the cleanliness of buildings.

\section{UNIVERSITY AND EDUCATIONAL INTELLIGENCE.}

LonDon.-The following doctorates have been conferred:-D.Sc. in Chemistry: Mr. W. H. Gibson, an internal student, of University College, for a thesis entitled "The Products of Nitration of Toluene." D.Sc. in Geology: Mr. C. B. Horwood, an external student, for a thesis entitled "The Gold Deposits of the Rand," and other papers. D.Sc. in Physiology: Dr. N. C. Lake, an external student, for a thesis No. 2509 , VOL. IOO] entitled "Report upon an Investigation into the Effects of Cold upon the Body," and other papers.

By his will the late Dr. Archibald Carmichael, who died in February of last year, has bequeathed the residue of his estate, subject to certain life-rents, to the University of Aberdeen. The value of the residue is estimated at about $12,000 l$., and the income thereof may be applied "for the advancement of the work of the medical side of the said University in such manner and subject to such regulations, as the Senatus Academicus of the same University may from time to time determine and think fit." The late Dr. Carmichael was a graduate of Aberdeen University.

THE Bureau of Education, India. has issued the seventh of its "Occasional Reports." It deals with the methods of school inspection in England, and is by Mr. H. G. Wyatt, inspector of schools in the Rawalpindi Division. There is much in the volume which will be of practical value in India, where the history of school instruction and of inspection has passed through phases similar to those in England. The respective functions of general and specialist inspectors are explained with considerable clearness, and the author points out that in India, where specialists are already being employed for certain subjects, such as science and handicraft, the chief lessons from the English experience are that the specialist should keep in close contact with the general territorial inspector and consult him in formulating his general recommendations; that he should see something of the general work of the school, and not confine his attention to his special subject. In the particular case of the inspection of secondary schools, Mr. Wyatt urges that the danger of specialist inspections is that they tend to disregard the aims and character of the school as a school, and consider it too much as an aggregate of classrooms. It is satisfactory to find that India has witnessed a revulsion from "grind" and from examination, and that inspection has ceased exclusively to regard the pupil and the results of instruction, and has tended to focus rather on the class and the teacher's methods.

A copy has been received of an essay by Mr. Fletcher Durell on the "Reform of the Princeton University Curriculum," which was awarded the Philip Le Boutillier prize in February, I9I6. Among other subjects discussed is the function of a college. The view generally held, the essay maintains, is that it is the principal aim of the secondary school to train the mind, so that it shall be a good working machine; that the leading function of the college is to have the pupil use his mind after it is thus trained so as to obtain a general world view; and that it is the essential aim of university education, or of other training subsequent to college work, to master some specialty or life-calling. In other words, after the school has laid the foundation, the college is to teach something about everything, and the university everything about something. But the functions of these three periods of education must overlap. During the secondary-school stage the pupil should assimilate large stores of varied information; at college the development of thought-power should continue, and as comprehensive a grasp as possible of the world's affairs should be secured. The American elective system of deciding a student's course of work is examined, and the treatment of the problem at Princeton University explained. The essay then suggests that to assist students in the choice of a faculty each department should work out a concise statement of the vital principles and most representative facts in its domain, and that in drawing up these statements attention should be directed to the efficiency or value aspects of the principles and facts. Princeton should, 